\title{
186. A Family of High Fetal Hemoglobin with Incidental Occurrence of an Unclassified Hemolytic Anemia
}

\author{
By Susumu Shibata, Takaoki MiYaJi, \\ Nobuyoshi Matsuda, and Yuzo OHBA*) \\ (Comm. by Taku KomaI, M.J.A. Sept. 12, 1966)
}

Recently we happened to observe several apparently healthy subjects with high concentration of fetal hemoglobin in blood while we were making hematological examinations of a family of a patient suffering from an unclassified hemolytic anemia associated with the production of a fairly large amount of fetal hemoglobin.

As is well known, in normal human fetus shortly before birth, a switch-over-change takes place in hemoglobin production from fetal hemoglobin $\left(\mathrm{Hb} \mathrm{F}=\alpha_{2} \gamma_{2}\right)$ to adult hemoglobin $\left(\mathrm{Hb} \mathrm{A}=\alpha_{2} \beta_{2}\right)$. In consequence, in normal human adults nearly the whole hemoglobin (as much as 96 per cent) is composed of $\mathrm{Hb} \mathrm{A}$, while $\mathrm{Hb} \mathrm{F}$ makes only a minor portion together with $\mathrm{Hb} \mathrm{A}_{2}\left(\alpha_{2} \delta_{2}\right)$ (less than 2 per cent) of the total hemoglobin.

Abnormally high level of $\mathrm{Hb} \mathrm{F}$ may be found in hemoglobinopathies with overt clinical symptoms (sickle-cell anemia, thalassemia, etc.). ${ }^{1)}$ Also, cases of congenital persistance of fetal hemoglobin apparently unconcerned with illness have been observed. ${ }^{2}{ }^{2}$

In the family studied by us no abnormal hemoglobin was demonstrated. And, the increase of $\mathrm{Hb} \mathrm{F}$ in apparently healthy subjects of the family reminds us of the cases of genetic persistence of fetal hemoglobin of the so-called African type and Greek type. ${ }^{3)}$ However, Betke-Kleihauer's staining of blood smear ${ }^{4)}$ has revealed the distinction that the distribution of $\mathrm{Hb} \mathrm{F}$ among the erythrocyte population is uneven, in contrast to the observation that individual erythrocytes are almost equal in $\mathrm{Hb} \mathrm{F}$ content in cases of hereditary persistance of $\mathrm{Hb} \mathrm{F}$. Accordingly, it seems that the propositus who had hemolytic anemia is a member of a family of high fetal hemoglobin of a new type. This paper deals with the result of our investigation on this interesting family, as well as the hemolytic anemia of the propositus.

Case record and family study. The propositus (male aged 25) had anemia and exertional dyspnea since early childhood. He has had slightly yellowish discoloration of the skin with cholelithiasis-

*) Department of Clinical Pathology, Yamaguchi Medical College, Ube. This investigation was supported in part by a PHS research grant (GM-09469-04) from the Division of General Medical Sciences, U. S. Public Health Service. 
like paroxysms nearly once a year from his primary school days. Two years ago he was told by his physician that he had splenomegaly (3 finger distance below the costal margin) and hepatomegaly (2 finger breadth). His gall bladder was not demonstrable by cholecystography.

Examination of his peripheral blood revealed a microcytic normochromic hemolytic anemia of moderate degree $(\mathrm{Hb} 7.6 \sim 8.3 \mathrm{~g} / \mathrm{dl}$; Ht, 21 23 per cent; RBC, $241 \sim 295 \times 10^{4} / \mathrm{mm}^{3}$; bilirubin $8.8 \mathrm{mg} / \mathrm{dl}$, total and $1.0 \mathrm{mg} / \mathrm{dl}$, direct; urine urobilinogen, strongly positive) with a considerably large number of spherocytes and spherocyte-like cells (occupying about 12 per cent of the cells) and diffusely basophilic cells (reticulocyte count, 14 per cent) (Fig. 1). Leukocyte and platelet counts were within the normal range.

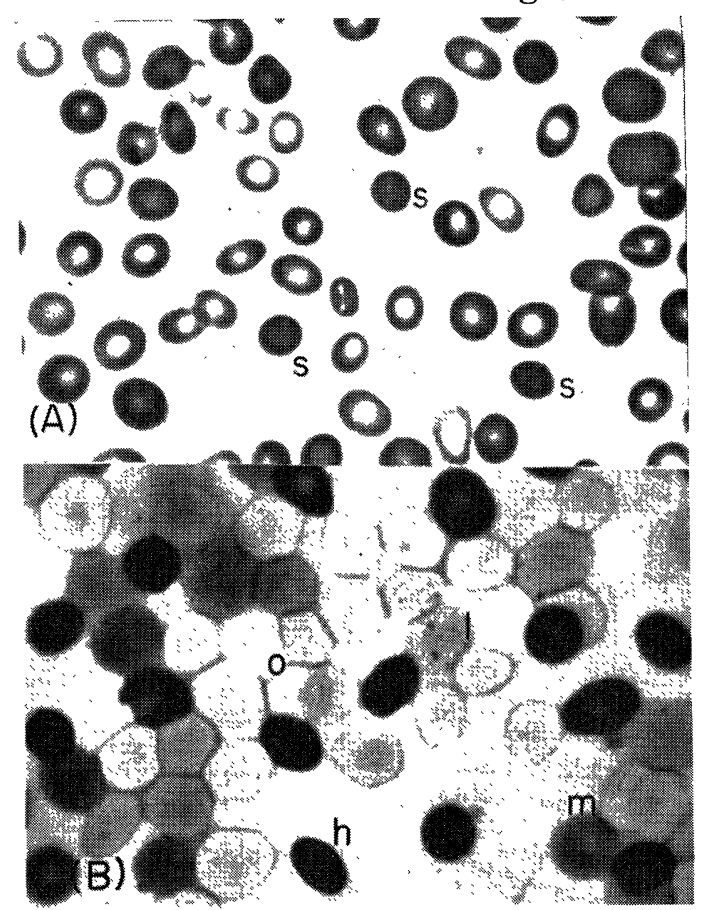

Fig. 1. Peripheral blood of the patient. (A) Wright stain :-s: spherocyte or spherocyte-like cell. (B) Betke-Kleihauer's stain:-h: cell with high $\mathrm{Hb} \mathrm{F}$ content; m: cell with medium $\mathrm{Hb} F$ content; l: cell with low $\mathrm{Hb} \mathrm{F}$ content; o: cell without $\mathrm{Hb} \mathrm{F}$.

The bone marrow showed erythrocytic hyperplasia, 71 per cent of the nucleated erythrocytes consisting of sideroblasts. The karyotype of the bone-marrow and peripheral blood cells, examined by Moorhead's method, ${ }^{\text {,) }}$ was normal.

The tests for acquired hemolytic anemia (Ham's acid test, Donath-Landsteiner's test and direct and indirect Coombs' tests) $)^{6)}$ 
were negative.

The osmotic fragility of erythrocytes of the fresh and stored blood (at $37^{\circ} \mathrm{C}$ for 24 hours) was slightly heightened $(0.50 \sim 0.40$ per cent and $0.75 \sim 0.30$ per cent $\mathrm{NaCl}$ solution, respectively). Autohemolysis test ${ }^{6)}$ also showed slight increase with the patient's blood alone, approached the normal range when glucose was added to the blood, and returned to normal limits by addition of ATP.

Intraerythrocytic formation of Heinz bodies was slightly accelerated with acetyl phenylhydrazine ${ }^{1)}(17.4$ per cent in the patient in comparison with 3.2 per cent in normal subject), but the activities of enzymes (G6PD, PK, ChE, DPNH diaphorase, LAP, GOT, GPT, Alk $\mathrm{Ph}, \mathrm{Ac} \mathrm{Ph}$, aldolase, $\mathrm{GSH}$, and $\mathrm{LDH}$ ) in erythrocytes were within the normal range.

The half life time $\left(\mathrm{Cr}^{51} \text { method }\right)^{6)}$ was distinctly shortened (10 days) without showing any significant accumulation of radio-activity in the spleen.

The hemolysate yielded a distinctly dense stripe suggestive of $\mathrm{Hb} \mathrm{F}$ when examined by agar gel electrophoresis ${ }^{7)}$ (pH 7.0) (Fig. 2).

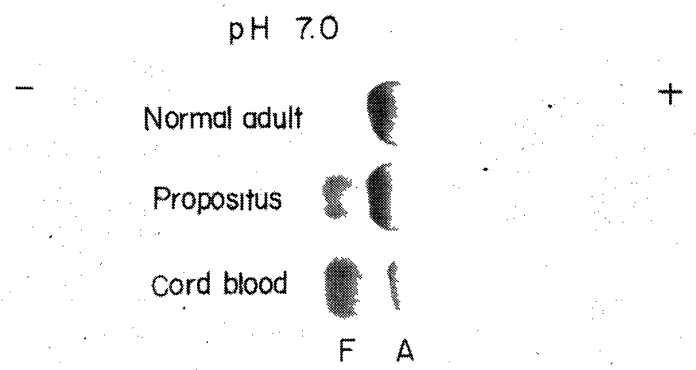

Fig. 2. Agar-gel electrophoresis ( $\mathrm{pH} \mathrm{7.0)}$ of the hemolysates. A: Hb A. $\mathrm{F}: \mathrm{Hb} \mathrm{F}$.

The $\mathrm{Hb} \mathrm{F}$ content of the hemolysate was 17.0 to 24.3 per cent by Singer's alkali denaturation test. ${ }^{8)}$ Amberlite IRC 50 chromatography (Allen's technique) $)^{9)}$ and the fingerprinting ${ }^{10)}$ (of the $\mathrm{F}_{\mathrm{II}}$ fraction) ascertained the identity of the increased hemoglobin constituent with $\mathrm{Hb} \mathrm{F}$.

The $\mathrm{Hb} \mathrm{F}$ content was distinctly different from cell to cell, when the blood smear specimen was treated by Betke-Kleihauer's staining for the demonstration of $\mathrm{Hb} \mathrm{F}$ in erythrocytes, as shown in Fig. 1. (Erythrocytes with high, medium and low contents of $\mathrm{Hb} \mathrm{F}$ were $19.5,29.6$, and 50.9 per cent. In the normal control specimen only 2 per cent of the cells contained $\mathrm{Hb} \mathrm{F}$ ).

The content of $\mathrm{Hb} \mathrm{A}_{2}$ in hemolysate ${ }^{11)}$ was normal, and the solubility of ferrohemoglobin ${ }^{11}$ was also within the normal limits. 
No abnormal hemoglobin was demonstrated by electrophoresis (agar, starch block and paper) ${ }^{11}$ and by chromatography (Amberlite IRC $50){ }^{11)}$

There was an significant relative increase of $\mathrm{LDH}_{4}$ in the isozyme

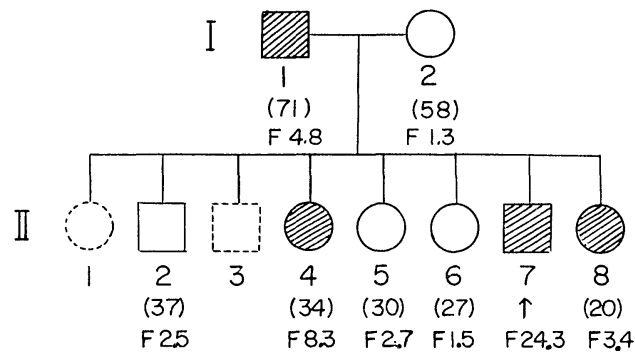

Fig. 3. Pedigree of the family. Oblique-striped: with high $\mathrm{Hb}$ F. II 1, 3: unexamined. $\uparrow$ : proband. Figures in parenthesis: age. F: $\mathrm{Hb} \mathrm{F}$ content of the hemolysate (for instance, F 2.5 signifies that $\mathrm{Hb} \mathrm{F}$ content is 2.5 per cent of the hemoglobin in the hemolysate). study of $\mathrm{LDH}$ (lactic dehydrogenase $)^{12)}$ of the hemolysate (the $\mathrm{LDH}$ activity was, however, almost normal, as described above).

The other members of the family (Fig. 3) were enjoying perfect health: they were hematologically normal (with normal $\mathrm{Hb} \quad \mathrm{A}_{2}$ content) except for the following two characteristic ab-

normalities:-

(i) The blood of the father (I-1) and two sisters (II-4, II-8) of the propositus had high $\mathrm{Hb} \mathrm{F}$ content (2.5 8.4 per cent) and the distribution of $\mathrm{Hb} \mathrm{F}$ in erythrocyte population was as uneven as in the patient.

(ii) In these members, the content of reduced glutathione (GSH) and DPNH diaphorase was more or less decreased.

Discussion and summary. It seems germane to interpret the case described above as an example of hemolytic anemia occurring in a family of "high $\mathrm{Hb} \mathrm{F}$ ". The trait was brought into the family by the father, and transmitted to his progeny including, the patient and his sisters as an autosomal dominant character.

The hemolytic anemia of the propositus seems to be of a genetic nature, since all the tests for acquired hemolytic anemia yielded negative results, and the patient had been ill from his early childhood. The anemia is characterized by microspherocytosis and by increase of $\mathrm{Hb} \mathrm{F}$.

The patient's anemia may be diagnosed as congenital spherocytic anemia ${ }^{13)}$ from the presence of microspherocytosis, but the absence of distinctly heightened osmotic fragility (as evident as that seen in the typical case) is not compatible with it. Also the lack of the accumulation of radioactivity in the spleen by in-vivo $\mathrm{Cr}^{51}$ test shows the distinction from this disease.

Remarkable reduction of the erythrocyte survival time and the 
slightly accelerated autohemolysis test are inconsistent with shunt hyperbilirubinemia. ${ }^{14)}$ The negative Coombs' test is unfavorable for the diagnosis of autoimmune hemolytic anemia. The enzymatic defect in erythrocytes does not seem to be the cause of the patient's anemia, since no significant abnormality in erythrocytic enzyme activities was demonstrated, except for the slightly increased formation of Heinz body with acetylphenylhydrazine.

The increase of $\mathrm{Hb} \mathrm{F}$ in blood observed in these cases is noteworthy, because it is suggestive of the possibility of $\beta$ - or $\delta \beta$-thalassemia. ${ }^{3)}$ However, this possibility is excluded by the morphology of erythrocytes distinct from that in thalassemia cells (lack of hypochromic microcytes and target cells, and presence of slightly increased osmotic fragility). The distinct sign of hemolytic anemia and uneven distribution of $\mathrm{Hb} \mathrm{F}$ in erythrocytic population are not found in the ordinary cases of hereditary persistance of fetal hemoglobin (African and Greek types). ${ }^{3}$

The only disease resembling this patient's anemia is a subtype of spherocytic hemolytic anemias of Dacie (1953), ${ }^{15)}$ in which microspherocytes with a minimal central pallor, of nearly normal osmotic fragility, and showing normal or increased autohemolysis, appear in the peripheral blood. Unfortunately, there is no mention of the alteration of $\mathrm{Hb} \mathrm{F}$ content in Dacie's description, which hinders our decision for the identity.

We, however, are led to the assumption that the patient had a congenital hemolytic anemia of doubtful classification. Also the demonstration of high $\mathrm{Hb} \mathrm{F}$ concentration without any clinical symptom in his relatives suggests that the patient has the hemolytic anemia owing to some unknown defect pertinent to his own genetic background of the high $\mathrm{Hb}-\mathrm{F}$ production. The increase of $\mathrm{Hb} \mathrm{F}$ in the patient which was particularly salient in comparison with the levels seen in his relatives may be interpreted as to be due to accentuation of the congenital defect by the hemolytic anemia.

The "high $\mathrm{Hb}$ F" of this family may involve the possibility of the reversion of hemoglobin production to the fetal type, since erythrocyte $\mathrm{LDH}$ isozyme is similar in pattern to that of fetus, but in reality the condition does not seem to be so simple. If the operator gene of $\gamma$ chain $\left(\mathrm{Hb} \mathrm{F}=\alpha_{2} \gamma_{2}\right)$ were persistently left derepressed after birth, intererythrocytic distribution of $\mathrm{Hb} \mathrm{F}$ would be uniform just like that seen in the "high $\mathrm{Hb} \mathrm{F}$ mutant". In the present family the situation is just the reverse, namely, individual erythrocytes vary in their $\mathrm{Hb} \mathrm{F}$ content.

According to Motulsky, ${ }^{16)}$ the structural genes of the $\beta, \gamma$, and 
$\delta$ chains are located on the same chromosome with an operator gene adjacent to them. The latter gene switches the production of the polypeptide chains from the $\gamma$ chain over to the $\beta$ and $\delta$ chains shortly prior to birth, and in the post-natal life the activity of the structural gene of the $\gamma$ chain is suppressed continuously to an almost zero level by another gene which is responsible for the formation of $\gamma$ chain repressor.

Presumably, the "high F" of the present family may be accounted for by a mutation of one of these genes, and the mutation is supposed to be less influential than, or somewhat different in character from, that pertinent to hereditary persistance of fetal hemoglobin which is seen in Negroes and Greeks.

Recently Marti (1963) $)^{1}$ found in some apparently healthy Swiss adults' blood slight increase (up to 3.4 per cent) of $\mathrm{Hb} \mathrm{F}$ which is unevenly distributed in erythrocytic population. Our observation reminds us of this report. Thus, our family may be classified into Marti's category of "high $\mathrm{Hb} \mathrm{F}$ ", but the degree of increase in $\mathrm{Hb}$ $\mathrm{F}$ seems to be too pronounced.

\section{References}

1) Marti, H. R.: Normale und Anomale Menschliche Hämoglobine. Springer (Berlin, Göttingen, Heidelberg) (1963).

2) Lehmann, H., and Huntsman, R. G.: Man's Haemoglobins. North-Holland (Amsterdam) (1966).

3) Motulsky, A. G.: Cold Spring Harbor Symposia on Quantitative Biology, 29, 399 (1964).

4) Kleihauer, E., Braun, H., und Betke, K.: Klin. Wschr., 35, 637 (1957).

5) Moorhead, P. S. et al.: Exper. Cell Res., 20, 613 (1960).

6) Dacie, J. V., and Lewis, S. M.: Practical Haematology, Churchill (London) (1963).

7) Shibata, S., and Iuchi, I.: Acta Haem. Jap., 24, 51 (1961).

8) Singer, K., Chernoff, A. I., and Singer, L.: Blood, 6, 413 (1951).

9) Allen, D. W., Schroeder, W. A., and Balog, J.: J. Amer. Chem. Soc., 80, 1628 (1958).

10) Ingram, V. M.: Biochim. Biophys. Acta, 28, 539 (1958).

11) Shibata, S.: Nihon-Ketsuekigaku-Zensho. Maruzen (Tokyo) 2, 216 (1963).

12) Yakulis, V. J. et al.: Amer. J. Clin. Path., 38, 378 (1962).

13) Dacie, J. V.: The Haemolytic Anemias, Congenital and Acquired. Part I. The Congenital Anemias. Churchill (London) (1961).

14) Vest, M.: Schweiz. Med. Wschr., 95, 842 (1965).

15) Dacie, J. V., et al.: Quart. J. Med., 22, 79 (1953).

16) Motulsky, A. G.: Proc. II Internat. Congr. Genet., p. 613 (1963). 